\title{
Vulnerability of Communities in Drought-Prone Areas during the COVID-19 Pandemic in Semarang City
}

\author{
Santy Paulla Dewi ${ }^{*}{ }^{*}$, Retno Susanti ${ }^{1}$ \\ ${ }^{1}$ Department of Urban and Regional Planning, Faculty of Engineering, Diponegoro University, J1. \\ Prof. Soedarto SH, Tembalang, Semarang, Indonesia
}

\begin{abstract}
Covid-19 pandemic still becomes a primary problem that influences many aspects. Some of the government efforts to reduce the spread of this virus are by continuing to urge people to comply with health protocols, one of which is by washing their hands after doing activities. This has implications for the water demand that rises and becomes an essential issues for drought-prone areas, especially when entering the dry season. Therefore, this study aims to examine the vulnerability of communities in drought-prone areas due to the increased demand for clean water during the pandemic. This research used a quantitative method by comparing water demand with the ability of water supply from the government and the community. The study uses secondary data from government agencies. The results of this study are to determine the vulnerability of drought-prone areas by dividing them into three zones, namely low, medium, and high. In addition, the results of this study are expected to provide recommendations to the government regarding the provision of clean water for the community during a pandemic. This is important because the efforts of the Semarang City government to overcome drought have tended to be reactive and unsustainable.
\end{abstract}

\section{Introduction}

Climate change is a global issue and has significant impacts on environmental and human activity sustainability [1]. However, climate change impacts diverse depending on the physical characteristics of the region and population [2]. For instance, the increase of temperatures and uncertain seasons generated drought [3] and deteriorate it in the future for certain areas $[4,5]$. A drought is an extreme event because of unbalanced water supply for a while as well as the low humidity level [1,6-8]. Meanwhile, the increase of population number, land-use conversion, and improper water management generate water competition escalation as well as reduce surface water contribute to the drought occurence $[5,9,10]$.

Drought is a seasonal disaster that takes place every year in Semarang City during the dry season (April to August). There are 24 sub-districts out of 117 sub-districts in Semarang City

* Corresponding author: santypaullad@gmail.com 
included as drought-prone areas. These areas are mostly found in the southern part of Semarang City that known as hilly areas with a topographical slope of $15 \%$. Likewise, these areas did not serve a piped-system of water services by the Regional Drinking Water Company (PDAM) so that the water demand provide through a community-based water supply system. However, the capacity of a community-based water supply systems was relatively low, they still relied on the government or other parties' subsidies.

There are $22-28 \%$ of the total inhabitants of drought-prone areas in Semarang are lowincome communities so that they have low capacity for water self-provisioning. Hence, they preferred to take the water from the river even the water quality was poor. As a result, they are susceptible to various health problems and made them more vulnerable [11]. Moreover, after the Covid-19 pandemic, their economic capacity was getting lower and increasing their vulnerability level. Vulnerability as an individual and community capacity responding shock and stress, including how they can cope, recover, or adapt to external pressures [12]. The vulnerability is determined from the resource availability and measured from three components such as adaptive capacity, sensitivity, and exposure [2, 10, 13].

Vulnerability is an implication of unstable climate change due to stress and shock [3, 1016]. Drought is included as a shock because it represents a depressed climate and unpredictable natural events. Meanwhile, the emergence of the Covid-19 pandemic that spreads throughout the world massively and rapidly, causing non-climate shocks. Therefore, drought and the Covid-19 pandemic made the vulnerable communities in drought-prone areas increase significantly [14]. Currently, several efforts on handling Covid-19 such as vaccination have decreased the cases (https://covid19.go.id). However, the community is still encouraged to implement the $5 \mathrm{M}$ habits (washing the hands, wearing the mask, physical distancing, avoiding the crowd, and minimizing mobility) to mitigate the transmission risk [17]. On the other hand, the implementation of 5 habits and the WASH (Water Supply Sanitation and Health) program increases household water consumption [18,19]. Hence, it is necessary to ensure a stable water supply during the pandemic [19-21]. A steady water provision is a primary challenge for several countries during the Covid-19 pandemic, especially in low-income countries $[11,19]$ and in drought-prone areas.

This study aims to identify the vulnerability level of communities in drought-prone areas due to climate change and the COVID-19 pandemic. This research divides into several stages: identifying drought conditions, analyzing community vulnerability levels based on indicators of exposure, sensitivity, and adaptability, mapping drought zones based on vulnerability levels, and analyzing drought management in Semarang City. Previous research related to drought and Covid-19 were emphasized on its relation to food security and the agricultural sector [3, 22-25]. Meanwhile, studies on analyzing pandemic Covid-19 correspond with community susceptibility were limited.

\section{Method}

This study emphasizes 24 drought-prone sub-districts in Semarang City. The data collection used the secondary data from several agencies such as Regional Disaster Management Agency (BPBD) Semarang, Central Bureau of Statistics (BPS) Semarang, Meteorology Climatology and Geophysics Agency (BMKG) Semarang, Environmental Services Semarang. The research method used descriptive method by identifying drought conditions; analyzing community vulnerability levels; and analyzing drought management in Semarang City. Meanwhile, identification drought zones of based on vulnerability level perform spatial analysis by overlaying maps between drought maps, population poverty maps, water network service maps, and water development programs. The classification of vulnerability levels includes high, medium, and low vulnerability. 


\section{Result and Discussion}

\subsection{Drought and Increased Demand for Clean Water in Semarang City}

The research conducted by the Indonesia Water Institute (IWI) found an increase in clean water consumption in Indonesia by up to 3 times during the Covid-19 pandemic. That is in line with the findings of $[18,19,21]$ that the Covid-19 pandemic has caused an increase in clean water consumption. The habit of WASH (Water Supply Sanitation and Health) activities in the community to prevent the Covid-19 virus has direct implications for increasing clean water consumption because the frequency of washing hands after activities increases and for bathing after activities. outdoors $[18,19]$.

According to UNESCO and Permen PU No. 14/2010, the standard for clean water needs, in general, is 60 liters per person per day. In more detail, the calculation of clean water needs is distinguishes according to regional characteristics:

- Rural areas, the need for water is 60 liters / per capita/day.

- Small towns, the need for water is 90 liters / per capita/day.

- Medium City with water needs of 110 liters / per capita/day.

- Big cities with a need of 130 liters / per capita/day.

- Metropolitan City with water needs of 150 liters / per capita/day.

Semarang City is a metropolitan city with a clean water requirement of 150 liters/capita/day. Research conducted by the Water Institute (IWI) found that the average community washes their hands more than ten times a day. This number has increased from $18 \%$ before the pandemic to $82 \%$ during the pandemic.

Table 1. Increased need for clean water in drought-prone areas after Covid-19.

\begin{tabular}{|c|c|c|c|c|}
\hline No & District & Sub-district & Population Number & Water Demand \\
\hline \multirow[t]{4}{*}{1.} & \multirow{4}{*}{ Mijen } & Karangmalang & 2.803 & 476.510 \\
\hline & & Polaman Wonolopo & 2.113 & 359.210 \\
\hline & & Ngadirgo & 6.268 & 1.065 .560 \\
\hline & & Bubakan & 2.068 & 351.560 \\
\hline \multirow[t]{3}{*}{2.} & \multirow[t]{3}{*}{ Banyumanik } & Pudakpayung & 25.092 & 4.265 .640 \\
\hline & & Gedawang & 10.021 & 1.703 .570 \\
\hline & & Jabungan & 4.209 & 715.530 \\
\hline \multirow[t]{3}{*}{3.} & \multirow[t]{3}{*}{ Candisari } & Candisari & 10.621 & 1.805 .570 \\
\hline & & Jomblang & 17.322 & 2.944 .740 \\
\hline & & Wonotingal & 7.130 & 1.212 .100 \\
\hline \multirow[t]{6}{*}{4.} & \multirow[t]{6}{*}{ Tugu } & Tugurejo & 6.941 & 1.179 .970 \\
\hline & & Jerakah & 2.860 & 486.200 \\
\hline & & Mangkang Wetan & 6.437 & 1.094 .290 \\
\hline & & Karanganyar & 3.940 & 669.800 \\
\hline & & Randugarut & 2.312 & 393.040 \\
\hline & & Mangunharjo & 6.307 & 1.072 .190 \\
\hline \multirow[t]{5}{*}{5.} & \multirow[t]{5}{*}{ Gunungpati } & Sukorejo & 15.628 & 2.656 .760 \\
\hline & & Kandri & 4.740 & 805.800 \\
\hline & & Nongkosawit & 5.561 & 945.370 \\
\hline & & Kalisegoro & 3.862 & 656.540 \\
\hline & & Gunungpati & 7.780 & 1.322 .600 \\
\hline \multirow[t]{3}{*}{6.} & \multirow[t]{3}{*}{ Tembalang } & Meteseh & 21,870 & 371.790 \\
\hline & & Mangunharjo & 11,811 & 2.007 .870 \\
\hline & & Rowosari & 14,599 & 2.481 .830 \\
\hline
\end{tabular}




\subsection{Community Vulnerability due to Drought and Covid-19 Pandemic}

Vulnerability can be seen from several indicators that differed concerning respect to the components. Table 2 revealed indicators of vulnerability from the components of exposure, sensitivity, and adaptive capacity.

Table 2. Indicators of Vulnerability of Drought-Prone Areas to the Covid-19 Pandemic.

\begin{tabular}{|c|c|c|}
\hline No & Vulnerability component & Indicator \\
\hline \multirow[t]{6}{*}{1} & \multirow[t]{6}{*}{ Exposure } & Population density \\
\hline & & Covid-19 pandemic \\
\hline & & Average temperature \\
\hline & & Sunshine duration \\
\hline & & Rainfall intensity \\
\hline & & Climate change \\
\hline \multirow[t]{5}{*}{2} & \multirow[t]{5}{*}{ Sensitivity } & Number of labor force \\
\hline & & Topographic and soil types \\
\hline & & Livelihood \\
\hline & & Water resource \\
\hline & & Percentage of poor people \\
\hline \multirow[t]{4}{*}{3} & \multirow[t]{4}{*}{ Adaptive Capacity } & Social capital \\
\hline & & Assets ownership \\
\hline & & Disaster preparedness \\
\hline & & Water services \\
\hline
\end{tabular}

\subsubsection{Exposure}

Exposure is the magnitude and duration of exposure related to climate change $[13,14]$ as well as shocks in the Covid-19 pandemic. Indicators in assessing the level of community exposure in drought-prone areas include aspects of population density, natural physical conditions, namely rainfall, and community livelihoods.

The average annual rainfall in Semarang City is $9,891 \mathrm{~mm}$ per year, and this distribution is uneven throughout the year. The average minimum temperature measured at the Semarang Climatology Station varied from $21.1^{\circ} \mathrm{C}$ in September to $24.6^{\circ} \mathrm{C}$ in May, and the average maximum temperature changed from $29.9^{\circ} \mathrm{C}$ to $32.9^{\circ} \mathrm{C}$. which is the actual ratio to the maximum solar irradiance, varying from $46 \%$ in December to $98 \%$ in August. Climate change has implications for the natural physical conditions of an area.

Meanwhile, exposure to the Covid-19 virus is considered a shocks to people in droughtprone areas. The vulnerability of people with low economic capacity in Semarang City is increasing after the Covid-19 pandemic. The population density of drought-prone areas in Semarang City is included as a low-level population density. The lowest population density is in Tugu District (10.5 people/ha), whereas the highest population density is in Candisari District (117 people/ha). However, the population density calculation did not consider the increase in migration data and emphasized on the bruto population density - the greater the population density in an area, the greater their competition for clean water.

\subsubsection{Sensitivity}

Sensitivity is the sensitivity level of a system to respond to or be affected by changes that occur both positively and negatively [2, 12-14]. In this context, sensitivity can measure people's vulnerability to stress (drought) and shocks (Covid-19 pandemic). The sensitivity indicators consist of the percentage of labor, topography and soil type, sources of water use, and the percentage of poor people in each sub-district in the study area. 
Table 3. The Population of drought-prone areas.

\begin{tabular}{|c|c|c|c|c|c|c|}
\hline No & District & Sub-district & $\begin{array}{c}\text { Total } \\
\text { Population } \\
\text { per District } \\
\text { (people) } \\
\end{array}$ & $\begin{array}{c}\text { Labor } \\
\text { Force } \\
\text { Population } \\
(\%) \\
\end{array}$ & $\begin{array}{c}\text { Population } \\
\text { density } \\
\text { (people/ha) }\end{array}$ & $\begin{array}{c}\text { Percentage of } \\
\text { the Number of } \\
\text { Poor } \\
\text { Population } \\
\end{array}$ \\
\hline \multirow[t]{4}{*}{1.} & \multirow[t]{4}{*}{ Mijen } & Karangmalang & \multirow{4}{*}{76.037} & \multirow{4}{*}{$54 \%$} & \multirow{4}{*}{13.2} & \multirow{4}{*}{$\begin{array}{c}27 \% \\
(18.824 \text { from } \\
76.037)\end{array}$} \\
\hline & & $\begin{array}{c}\text { Polaman } \\
\text { Wonolopo }\end{array}$ & & & & \\
\hline & & Ngadirgo & & & & \\
\hline & & Bubakan & & & & \\
\hline \multirow[t]{3}{*}{2.} & \multirow[t]{3}{*}{ Banyumanik } & Pudakpayung & \multirow{3}{*}{164.953} & \multirow{3}{*}{$57 \%$} & \multirow{3}{*}{64.2} & \multirow{3}{*}{$\begin{array}{c}23 \% \\
(36.3661 \text { from } \\
164.953)\end{array}$} \\
\hline & & Gedawang & & & & \\
\hline & & Jabungan & & & & \\
\hline \multirow[t]{3}{*}{3.} & \multirow[t]{3}{*}{ Candisari } & Candisari & \multirow{3}{*}{76.857} & \multirow{3}{*}{$49 \%$} & \multirow{3}{*}{117.5} & \multirow{3}{*}{$\begin{array}{c}28 \% \\
(21.276 \text { from } \\
76.857)\end{array}$} \\
\hline & & Jomblang & & & & \\
\hline & & Wonotingal & & & & \\
\hline \multirow[t]{7}{*}{4.} & \multirow[t]{7}{*}{ Tugu } & Tugurejo & \multirow{7}{*}{33.333} & \multirow{7}{*}{$59 \%$} & \multirow{7}{*}{10.5} & \multirow{7}{*}{$\begin{array}{c}27 \% \\
(8.563 \text { from } \\
33.333)\end{array}$} \\
\hline & & Jerakah & & & & \\
\hline & & Mangkang & & & & \\
\hline & & Wetan & & & & \\
\hline & & Karanganyar & & & & \\
\hline & & Randugarut & & & & \\
\hline & & Mangunharjo & & & & \\
\hline \multirow[t]{5}{*}{5.} & \multirow[t]{5}{*}{ Gunungpati } & Sukorejo & \multirow{5}{*}{118.760} & \multirow{5}{*}{$32 \%$} & \multirow{5}{*}{21.9} & \multirow{5}{*}{$\begin{array}{c}22 \% \\
(24.435 \text { from } \\
118.760)\end{array}$} \\
\hline & & Kandri & & & & \\
\hline & & Nongkosawit & & & & \\
\hline & & Kalisegoro & & & & \\
\hline & & Gunungpati & & & & \\
\hline \multirow[t]{3}{*}{6.} & \multirow[t]{3}{*}{ Tembalang } & Meteseh & \multirow{3}{*}{209.504} & & & $24 \%$ \\
\hline & & Mangunharjo & & $56 \%$ & 47.4 & (45.747 from \\
\hline & & Rowosari & & & & 209.504) \\
\hline
\end{tabular}

Source: BPS of Semarang City, 2020

The percentage of workers in the research area ranges from $32-59 \%$. It represented the community capability in an economic perspective regarding coping with shock and stress. Hence, social and economic characteristics affect their level of sensitivity to exposure. Candisari sub-district has the highest poverty rate so that it has a greater vulnerability. Meanwhile, Gunungpati Sub-district has the lowest labor force at $32 \%$, meaning that the ratio between communities who earn money less than communities who work and paid. The impact of climate change and the shock of the Covid-19 pandemic will provide greater vulnerability to the poor, the elderly, children, and the marginalized [13].

On the other hand, the physical characteristics influence the susceptibility to drought which is reviewed from the topographical condition and soil type. Topographically, Semarang City consists of two different landscapes, namely the northern part of Semarang City with a slope of $0-2 \%$, and hilly areas located in the southern part with a slope of $2-40 \%$. Topography is one factor in soil formation, which also affects the amount of water in the soil mass, the depth of groundwater, and the ability of the soil to resist erosion [26]. The slope of an area impacts the volume of runoff to the downstream area, so interventions are needed to meet the needs of clean water in the upstream area. Drought-prone areas are entirely on topographical slopes above $15 \%$. Soil type also affects water availability capacity (AWC), such as the ability of the soil to store water for plant roots [27]. Table 4 shows the type of soil that also determines the amount of natural water uptake and the amount of runoff.

Table 4. Soil type and the characteristic. 


\begin{tabular}{|c|c|c|c|c|}
\hline No & Soil type & District & Percentage & Characteristic \\
\hline 1. & $\begin{array}{l}\text { Dark-brown } \\
\text { Mediterian }\end{array}$ & $\begin{array}{l}\text { Tugu, Ngaliyan, } \\
\text { Gunungpati, } \\
\text { Candisari, } \\
\text { Tembalang, } \\
\text { Banyumanik }\end{array}$ & $36 \%$ & $\begin{array}{l}\text { Moderate absorption and } \\
\text { permeability, sensitive to } \\
\text { erosion and has an AWC of } \\
200 \mathrm{~mm} / \mathrm{m}\end{array}$ \\
\hline 2. & $\begin{array}{l}\text { Latosol reddish } \\
\text { dark brown }\end{array}$ & Mijen, Gunungpati & $26 \%$ & $\begin{array}{l}\text { In general, the soil texture } \\
\text { is clayey, the soil structure } \\
\text { is a crumb with a loose } \\
\text { consistency, has a rather } \\
\text { fast to slightly slow } \\
\text { infiltration, the soil power } \\
\text { is quite good, quite } \\
\text { resistant to soil erosion }\end{array}$ \\
\hline 3. & $\begin{array}{c}\text { Alluvial } \\
\text { hydrosate, } \\
\text { grumosol dark } \\
\text { gray, latosol dark } \\
\text { brown, regosol } \\
\text { dark gray }\end{array}$ & $\begin{array}{l}\text { Tugu, Gunungpati, } \\
\text { Mijen }\end{array}$ & $22 \%$ & $\begin{array}{l}\text { Clay or sandy soil texture } \\
\text { so that it tends to be hard } \\
\text { when it is dry or has a low } \\
\text { moisture content; the } \\
\text { potential for severe drought }\end{array}$ \\
\hline 4. & $\begin{array}{l}\text { Alluvial gray and } \\
\text { dark brown }\end{array}$ & $\begin{array}{l}\text { Other districts } \\
\text { (lowland) }\end{array}$ & $22 \%$ & $\begin{array}{l}\text { Fertile and suitable for } \\
\text { agriculture and secondary } \\
\text { crops }\end{array}$ \\
\hline
\end{tabular}

Source: Asfaw et al. (2021), Hastanti \& Purwanto (2020)

Drought-prone areas have soil types with high erodibility properties and less absorption level. When there is exposure to extreme climate change in drought-prone areas, they cannot respond appropriately, making these areas more vulnerable. During the Covid-19 pandemic, the water consumption increased by 20 liters/person/day [29]. They have no accessed to water resources during the dry season, so that they have to buy 20 liters of water every two days for Rp. 4,000 (especially for food and drink). Meanwhile, people take water from the river for bathing and washing, whether manually (shoulder pole) or use motorcycle vehicles to transport jerry cans of water.

\subsubsection{Adaptive Capacity}

Adaptive capacity describes how individuals or social groups adjust, recover, and adapt from the stresses and shocks [2, 12-13]. The indicators used to assess the adaptive capacity of communities in drought-prone areas are by identifying social networks, disaster preparedness groups, assets ownership, Community Based Water Supply and Sanitation Program (PAMSIMAS), or PDAM water services, and government assistance to reduce community vulnerability due to drought the Covid-19 pandemic.

The Semarang City Government established the Disaster Prepared Sub-District (KSB) program to reduce the vulnerability of communities in disaster-prone areas. KSB is a subdistrict that can adapt to various disaster threats independently. This program was funded from several sources such as Regional Revenue and Expenditure Budget (APBD) Semarang, donor agency Bintari Foundation that also cooperated with Regional development planning agency (Bappeda) Semarang, and Universitas Diponegoro. 
Table 5. Availability of Disaster Prepared Sub-District in the Study Area.

\begin{tabular}{|c|c|c|c|c|c|}
\hline No & District & Sub-district & $\begin{array}{l}\text { Disaster } \\
\text { Prepared } \\
\text { Sub- } \\
\text { district }\end{array}$ & $\begin{array}{c}\text { Year } \\
\text { Established }\end{array}$ & Budget Source \\
\hline \multirow[t]{4}{*}{1.} & \multirow[t]{4}{*}{ Mijen } & Karangmalang & $\mathrm{V}$ & 2019 & APBD \\
\hline & & $\begin{array}{c}\text { Polaman } \\
\text { Wonolopo }\end{array}$ & \multicolumn{3}{|c|}{-} \\
\hline & & Ngadirgo & \multicolumn{3}{|c|}{-} \\
\hline & & Bubakan & \multicolumn{3}{|c|}{-} \\
\hline \multirow[t]{3}{*}{2.} & \multirow[t]{3}{*}{ Banyumanik } & Pudakpayung & $\mathrm{V}$ & 2018 & APBD \\
\hline & & Gedawang & $\mathrm{V}$ & 2019 & APBD \\
\hline & & Jabungan & $\mathrm{V}$ & 2019 & APBD \\
\hline \multirow[t]{3}{*}{3.} & \multirow[t]{3}{*}{ Candisari } & Candisari & $\mathrm{V}$ & 2017 & APBD \\
\hline & & Jomblang & $\mathrm{V}$ & 2011 & $\begin{array}{l}\text { Cooperation of Bappeda, } \\
\text { Universitas Diponegoro } \\
\text { and Bintari Foundation }\end{array}$ \\
\hline & & Wonotingal & $\mathrm{V}$ & 2021 & APBD \\
\hline \multirow[t]{6}{*}{4.} & \multirow[t]{6}{*}{ Tugu } & Tugurejo & $\mathrm{V}$ & 2020 & APBD \\
\hline & & Jerakah & \multicolumn{3}{|r|}{ D } \\
\hline & & $\begin{array}{l}\text { Mangkang } \\
\text { Wetan }\end{array}$ & $\mathrm{V}$ & 2013 & $\begin{array}{l}\text { Cooperation of Bappeda, } \\
\text { Universitas Diponegoro } \\
\text { and Bintari Foundation }\end{array}$ \\
\hline & & Karanganyar & \multicolumn{3}{|c|}{-} \\
\hline & & Randugarut & $\mathrm{V}$ & 2020 & APBD \\
\hline & & Mangunharjo & V & 2013 & $\begin{array}{l}\text { Cooperation of Bappeda, } \\
\text { Universitas Diponegoro } \\
\text { and Bintari Foundation }\end{array}$ \\
\hline \multirow[t]{5}{*}{5.} & \multirow[t]{5}{*}{ Gunungpati } & Sukorejo & $\mathrm{V}$ & 2011 & APBD \\
\hline & & Kandri & V & 2020 & APBD \\
\hline & & Nongkosawit & \multicolumn{3}{|c|}{-} \\
\hline & & Kalisegoro & \multicolumn{3}{|c|}{-} \\
\hline & & Gunungpati & \multicolumn{3}{|c|}{ 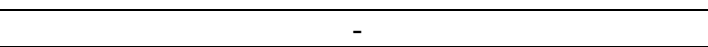 } \\
\hline \multirow[t]{3}{*}{6.} & \multirow[t]{3}{*}{ Tembalang } & Meteseh & $\mathrm{V}$ & 2017 & APBD \\
\hline & & Mangunharjo & \multicolumn{3}{|c|}{ - } \\
\hline & & Rowosari & V & 2011 & APBD \\
\hline
\end{tabular}

Source: BPBD Kota Semarang, 2021

Most the drought-prone sub-districts have KSB so that the stakeholder, as well as the community, have the comprehension about the disasters and mitigations efforts. Likewise, the community can recognize threats (disaster) in their area, organize local resources to reduce vulnerability and, increase capacity to reduce disaster risk.

However, the implementation of KSB dealt with several obstacles, such as limited funding sources so that relied on government support and inadequate quality of human resources. Currently, the KSB program is still exists and considered as one of the primary program-related disasters management. It means that the adaptive capacity of the communities in drought-prone areas needs to enhance through supervision from the government, universities, and private sectors. By regular and comprehensive supervising, the community will enhance its capacity.

\subsection{Drought Management in Semarang City}

Since the Covid-19 pandemic, the government refocused the APBD to handle the Covid-19 impact. As a consequence, several developments were postponed including plans for 
developing and improving water infrastructure. Several development programs have been planned, such as providing raw water and increasing households using drinking water, natural resource protection, and conservation programs. The program includes improving protected area management: maintaining and revitalizing water catchment areas or hydrological function areas to ensure the availability of natural resources; water and soil fertility. In addition, the government support PAMSIMAS program by as isntancing the community that gets drinking water grant from s collaboration between the Ministry of Public Works and Spatial Planning PUPR and Australian AID. As a result, household numbers that connect to the drinking water system increased (3.39\% compared to the previous year).

The Covid-19 pandemic has given new attention to the importance of managing and providing adequate water and sanitation infrastructure. Ensuring a stable supply of drinking water during a pandemic is key in ensuring the health of a population and preventing the spread of the virus [19-21], and reducing the impact of future pandemics. Strategic plans must formulate for emergency response and water resources management in the short and long term. Need to do the integrated, inclusive, and sustainable development of disaster resilience among various stakeholders. So that in the future, Semarang City, which is prone to natural disasters, is resilient to climate pressures and shocks that occur.

\subsection{Vulnerability Zone Mapping}

The result of identifying the drought and increasing the water demand, the community's vulnerability due to the drought and the Covid-19 pandemic, as well as the management of drought management in the city of Semarang overlaid to determine the maps of vulnerability zone. The mapping of vulnerable zones shows the most vulnerability area to drought and the Covid-19 pandemic that was determined from scoring data on drought areas, population poverty, clean water network services, and the existence of $\mathrm{KSB}$, and water development programs.

The community vulnerability map in the drought area of Semarang City shows the level of vulnerability that divide into low, medium, and high levels. Sub-districts that have a low level of vulnerability are Mangunharjo (Tugu), Karangmalang, Kandri, Nongkosawit, Gedawang, Jabungan, and Mangunharjo (Tembalang). $71 \%$ of the sub-districts of low level of vulnerability sub-district already have KSB; clean water piped networks serve $28 \%$ of the sub-district; $43 \%$ of sub-districts have bio pores and infiltration wells. Similarly, all subdistricts have a relatively low number of poor people. Medium vulnerability level consist of Polaman Wonolopo, Ngadirgo, Bubakan, Candi, Wonotingal, Jerakah, Randugarut, Kalisegoro, Gunungpati, Meteseh, and Rowosari sub-districts. There are 42\% sub-districts have KSB; clean water piped networks served of sub-districts (58\%), $8 \%$ of sub-districts have bio pores. In addition, the number of poor people is below the average to above the average percentage of poor people in the area-drought in Semarang. Sub-district that have a high level of vulnerability are Pudakpayung, Tugurejo, Mangkang Wetan, Karanganyar, and Sukorejo. $80 \%$ of sub-districts with a high level of vulnerability already have KSB; clean water pipelines serve $40 \%$ of sub-districts; $20 \%$ of sub-district have bio pores and infiltration wells. Nevertheless, the number of poor people in all sub-district is above the average percentage of poor people in drought areas in Semarang City. 


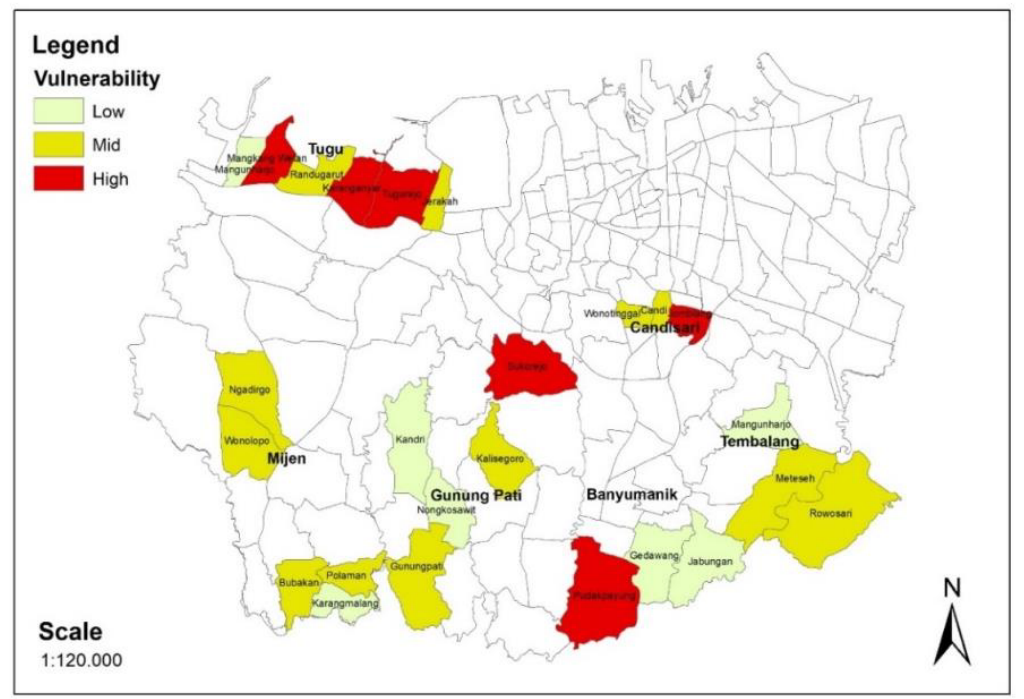

Fig. 2. Map of community vulnerability.

Based on community vulnerability mapping, the most influencing factor in mapping vulnerability zoning is the percentage of poor people. The higher the percentage of poor people in a sub-district to the district population, the higher the vulnerability in drought areas during the Covid-19 pandemic. The community bore the disaster impact due to economic vulnerability and resilience, whereas the lowest economic level community will perceive the worst impact on the disaster.

\section{Conclusion}

Drought is an annual natural disaster in 24 sub-districts in Semarang. Based on the socialeconomic characteristic of the inhabitants of these sub-districts can be categorized as a vulnerable group. Hence, their vulnerability increased when the drought occurs during the Covid-19 pandemic. The water demand increase along with the effort to mitigate the covid19 infection. As a result, the vulnerable communities in drought-prone areas have to pay more for the water supply. The Covid-19 pandemic has given new attention to the importance of managing and providing adequate air and sanitation infrastructure. The Semarang City Government is necessary to develop an integrated, inclusive, and sustainable disaster resilience strategy involving various stakeholders.

\section{References}

1. R. Zhao, H. Wang, J. Chen, G. Fu, C. Zhan, H. Yang, Ecol. Indic., 121, 107107 (2021)

2. A. Asfaw, A. Bantider, B. Simane, A. Hassen, Heliyon, 7, e06761 (2021)

3. M. Keshavarz, H. Maleksaeidi, E. Karami, Int. J. Disaster Risk Reduct., 21, 223 (2017)

4. D. A. Wilhite, M. V. K. Sivakumar, R. Pulwarty, Weather Clim. Extrem., 3, 4 (2014)

5. Z. Noorisameleh, S. Khaledi, A. Shakiba, P. Z. Firouzabadi, W. A. Gough, M. M. Q. Mirza, Water Sci. Eng., (2020)

6. T. G. Huntington, J. Hydrol., 319, 83 (2006)

7. K. E. Trenberth, A. Dai, G. Van Der Schrier, P. D. Jones, J. Barichivich, K. R. Briffa, J. Sheffield, Nat. Clim. Chang., 4, 17 (2014) 
8. B. I. Cook, R. Seager, J. E. Smerdon, Geophys. Res. Lett., 41, 7298 (2014)

9. B. Bates, Z. Kundzewicz, S. Wu, Climate change and water (Intergovernmental Panel on Climate Change Secretariat, 2008)

10. M. Parry, M. L. Parry, O. Canziani, J. Palutikof, P. der Linden, C. Hanson, et al., Climate change 2007-impacts, adaptation and vulnerability: working group II contribution to the fourth assessment report of the IPCC (Cambridge University Press, 2007)

11. J. Stoler, J. D. Miller, A. Brewis, M. C. Freeman, L. M. Harris, W. Jepson, A. L. Pearson, A. Y. Rosinger, S. H. Shah, C. Staddon, et al., Int. J. Hyg. Environ. Health, 234, 113715 (2021)

12. P. M. Kelly, W. N. Adger, Clim. Change, 47, 325 (2000)

13. M. B. Hahn, A. M. Riederer, S. O. Foster, Glob. Environ. Chang., 19, 74 (2009)

14. K. U. Shah, H. B. Dulal, C. Johnson, A. Baptiste, Geoforum, 47, 125 (2013)

15. F. Nasrnia, N. Ashktorab, Ecol. Indic., 128, 107817 (2021)

16. M. Prowse, L. Scott, (2008)

17. WHO, Publ. Online March (2020)

18. S. Cotterill, S. Bunney, E. Lawson, A. Chisholm, R. Farmani, P. Melville-Shreeve, Water Environ. J., 34, 715 (2020)

19. A. Kalbusch, E. Henning, M. P. Brikalski, F. V. de Luca, A. C. Konrath, Resour. Conserv. Recycl., 163, 105098 (2020)

20. M. J. Neal, Water Int., 45, 435 (2020)

21. B. Sivakumar, (2020)

22. M. Huss, M. Brander, M. Kassie, U. Ehlert, T. Bernauer, Glob. Food Sec., 28, 100468 (2021)

23. V. Iese, M. Wairiu, G. M. Hickey, D. Ugalde, D. H. Salili, J. Walenenea Jr, T. Tabe, M. Keremama, C. Teva, O. Navunicagi, et al., Agric. Syst., 190, 103099 (2021)

24. S. Han, P. K. Roy, I. Hossain, K.-H. Byun, C. Choi, S.-D. Ha, Trends Food Sci. Technol., (2021)

25. B. Talukder, K. W. Hipel, J. Orbinski, et al., Curr. Res. Environ. Sustain., 3, 100033 (2021)

26. K. E. Schilling, P. Jacobson, River Res. Appl., 28, 1417 (2012)

27. Q. Styc, P. Lagacherie, Geoderma, 391, 114968 (2021)

28. B. W. Hastanti, P. Purwanto, J. Penelit. Hutan Dan Konserv. Alam, 17, 1 (2020)

29. S. Bellizzi, C. M. P. Napodano, M. Fiamma, O. A. Maher, Public Health, 183, 46 (2020) 